\title{
PRODUCTION OF A NOVEL RED PIGMENT, RUBROLONE, BY STREPTOMYCES ECHINORUBER SP. NOV.
}

\section{TAXONOMY, FERMENTATION AND PARTIAL PURIFICATION}

\author{
N. J. Palleroni, K. E. Reichelt, D. Mueller, R. Epps, B. Tabenkin, \\ D. N. Bull, W. SChüEP and J. Berger \\ Chemical Research Department, Hoffmann-La Roche Inc., \\ Nutley, New Jersey 07110, U.S.A.
}

(Received for publication August 28, 1978)

\begin{abstract}
A taxonomic study of Streptomyces X-14077 (NRRL 8144), which produces a watersoluble purple-red pigment complex, revealed it to be a new species which has been named Streptomyces echinoruber sp. nov. The pigment complex was produced in deep culture fermentation and isolated by solvent extraction and concentration. The major pigment component, rubrolone, has low toxicity and may have potential as a food coloring agent. It appears to be devoid of antibiotic activity.
\end{abstract}

In the course of our search for non-toxic red pigment of microbial origin for use as food colors, an actinomycete was isolated from a soil sample collected in Argentina. When grown in shake culture on a number of liquid media, this organism produced a beautiful water-soluble, purple-red pigment complex.

This report deals with the taxonomy of this new organism, which we propose to name Streptomyces echinoruber sp. nov., and the production, isolation and biological properties of the purified major component, rubrolone, of the pigment complex. A preliminary description of these findings has been reported. ${ }^{1)}$ Additional studies on the isolation, identification and physicochemical properties of the pigment will be reported in the following paper. ${ }^{2)}$ Food coloring properties of the pigment will be reported. ${ }^{3 \prime}$

\section{Taxonomy of the Producing Organism}

The organism grows easily in many standard actinomycete media, including the ISP media (Difco) that are recommended by ShIRLING and GotTLIEB ${ }^{4)}$ for the description of Streptomyces cultures. The characteristics of the aerial growth, spore mass color, color of the reverse substrate mycelium and production of soluble pigment in these various media are described in Table 1. The agar plates were incubated at $28^{\circ} \mathrm{C}$, and the results were recorded after 14 days of incubation.

Carbon utilization tests were performed in the ISP-9 medium (Difco). Other physiological tests including sodium chloride tolerance $(0,3,5,7$, and $10 \% \mathrm{NaCl})$, reduction of nitrate, and hydrolysis of casein were carried out by the methods of Gordon and $\mathrm{SMITH}^{5)}$. Hydrolysis of starch was determined with Actinomyces broth (Difco) containing $0.25 \%$ of soluble starch and $2 \%$ agar. After incubation the plates were flooded with iodine-KI solution. Gelatin liquefaction was determined according to the method of SKerman ${ }^{6)}$ modified by the use of Actinomyces broth (Difco) instead of nutrient broth. Decomposition of adenine, xanthine, hypoxanthine, and tyrosine were determined by the method of Gordon $^{7)}$. The action on skim milk was tested on $10 \%$ skim milk powder (Difco) in water. 
Table 1. Growth characteristics of strain X-14077 in various agar media

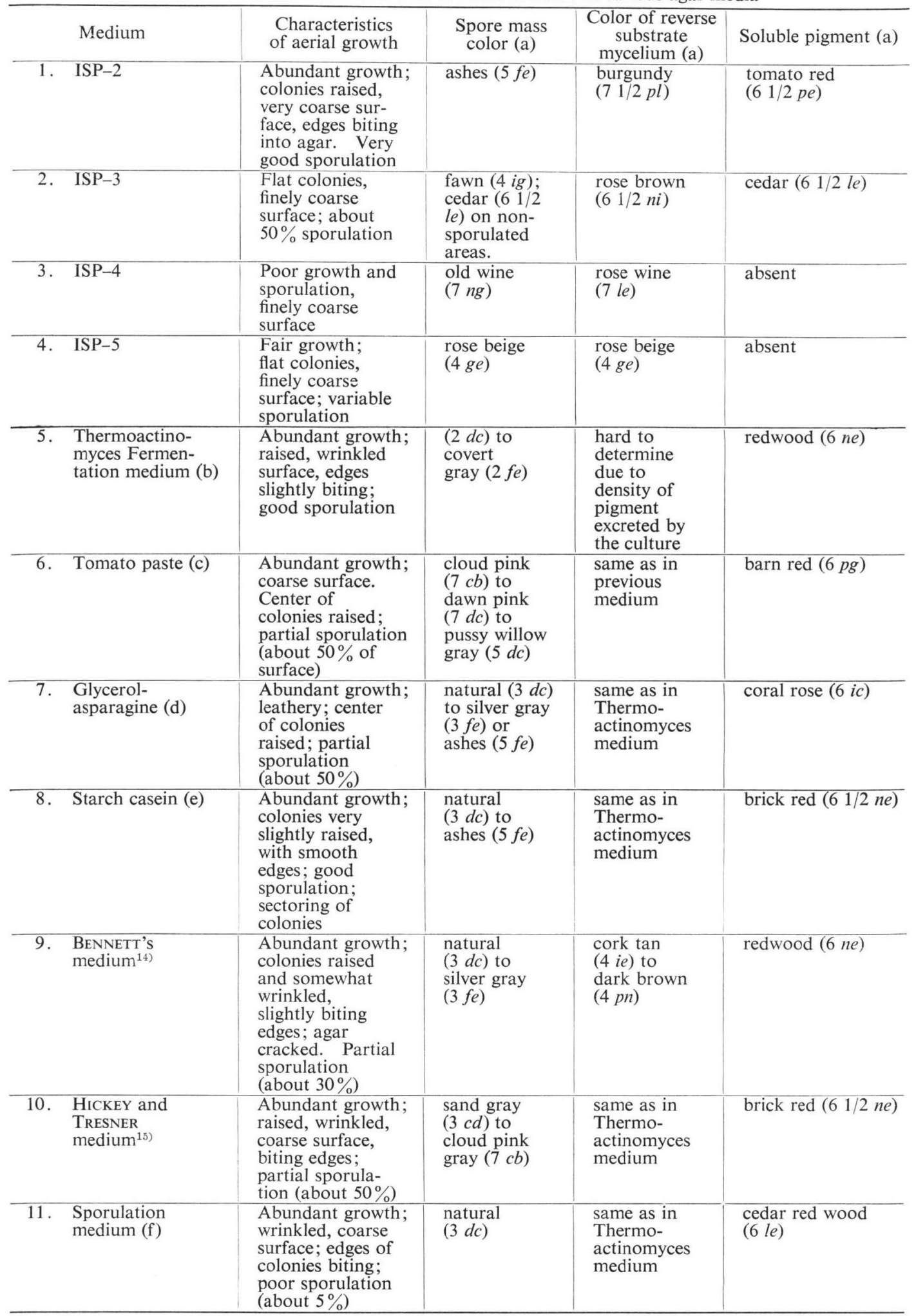


Table 1. (continued)

(a) The color scheme was taken from the Color Harmony Manual, 4th edition, 1958 (Container Corporation of America, Chicago).

(b) Thermoactinomyces fermentation broth (Difco) to which $1.5 \%$ agar was added. This medium is no longer commercially available. The composition is as follows: Tryptone, $0.5 \%$; yeast extract, $0.2 \%$; Soytone, $0.2 \%$; white potato dextrin, $1.0 \%$; D-mannitol, $0.5 \% ; \mathrm{MgSO}_{4}, 0.02 \% ; \mathrm{Fe}\left(\mathrm{NH}_{4}\right)_{2} \mathrm{SO}_{4}, 0.001 \%$; $\mathrm{ZnCl}_{2}, 2.1 \mu \mathrm{g} / \mathrm{ml} ; \mathrm{MnCl}_{2}, 1.8 \mu \mathrm{g} / \mathrm{ml} ; \mathrm{CuSO}_{4}, 0.2 \mu \mathrm{g} / \mathrm{ml} ; \mathrm{Co}\left(\mathrm{NO}_{3}\right)_{2}, 0.5 \mu \mathrm{g} / \mathrm{ml} ; \mathrm{H}_{3} \mathrm{BO}_{3}, 0.6 \mu \mathrm{g} / \mathrm{ml} ; \mathrm{pH} 7.2$.

(c) Glucose, $1.0 \% ; \mathrm{K}_{2} \mathrm{HPO}_{4}, 0.1 \%$; tomato paste, $2.0 \%$; Wilson's Medopeptone, $0.1 \% ; \mathrm{CaCO}_{3}, 0.2 \%$; agar, $1.5 \%$; pH $6.8 \sim 7.3$.

(d) Glycerol, $1.0 \%$; asparagine, $0.1 \% ; \mathrm{K}_{2} \mathrm{HPO}_{4}, 0.1 \%$; agar, $2.0 \%$; $\mathrm{pH} 7.0$. This medium is the same as ISP-5 with the exclusion of the trace salts.

(e) Modified from the medium described by WAKSMAN ${ }^{13)}$ by the addition of $0.05 \% \mathrm{MgSO}_{4}$.

(f) Medium No. 5, American Type Culture Collection Catalogue of Strains, 12th edition, 1976 (American Type Culture Collection, Rockville, Maryland).

Fig. 1. Strain X-14077. Spore chains. 14 days on ISP-3 agar. $\times 3,000$.

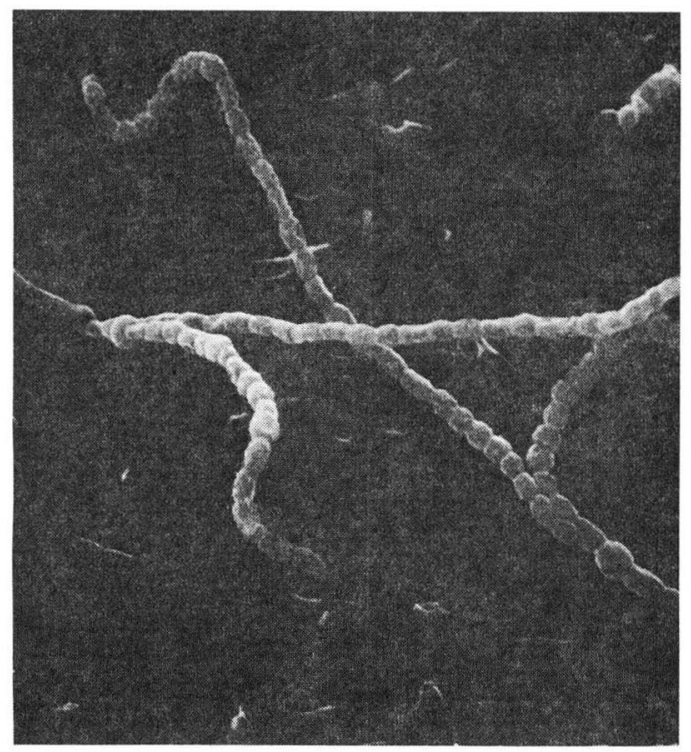

Fig. 2. Strain X-14077. Spore chains. 14 days on ISP-3 agar. $\times 10,000$.

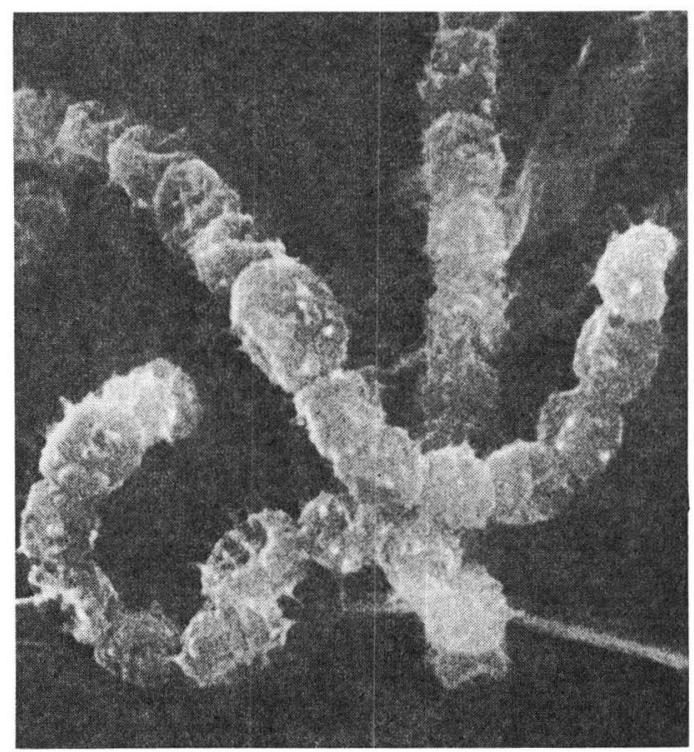

The ability of the culture to grow at various temperatures $\left(10,20,24,28,36\right.$, and $\left.45^{\circ} \mathrm{C}\right)$ was determined with tryptone-yeast broth (medium ISP-1, Difco). Incubation was done in a well-regulated water bath with rotary shaking.

With the exceptions indicated below, a 2-day old culture in ISP-1 broth was used as inoculum for the different tests. The seed culture was homogenized, centrifuged, and the pellet resuspended in sterile saline before use as inoculum. In the case of media $\$ 5$ through $\# 11$ (Table 1 ), the inoculum was taken from a culture grown in Thermoactinomyces Fermentation broth (Difco). Cell wall analysis was performed by the method of BECKER et al. ${ }^{81} \quad$ Sensitivity to various antibiotics was tested using 6.35 -mm commercial antibiotic discs (Baltimore Biological Laboratories, Cockeysville, Md.) with seeded tray of HLR

Morphological Characteristics.

Strain X-14077 produces a non-fragmenting substrate mycelium and an aerial mycelium forming spore chains. After $11 \sim 14$ days of incubation at $28^{\circ} \mathrm{C}$ in various media abundant sporophores can be observed under a microscope with low magnification (Fig. 1). The spore chains have the shape of spirals, 
hooks and loops. The spirals are either rudimentary or more tightly coiled, and belong to the retinaculum apertum type. Each chain contains more than 10 but less than 50 spores. The spores are globose, measuring from $1.2 \sim 1.5 \mu \mathrm{m}$ by $1.1 \sim 1.4 \mu \mathrm{m}$, and their surface is spiny (Fig. 2 ). The cell wall contains the $\mathrm{L}, \mathrm{L}$-isomer of diaminopimelic acid. This property, taken together with the above morphological characteristics, show that the organism belongs to the genus Streptomyces ${ }^{9}$.

The characteristics of the aerial growth, spore mass color, color of reverse mycelium and production of red soluble pigment on various solid media are given in Table 1. A comparison of strain X-14077 with Streptomyces species described in Bergey's Manual ${ }^{10 \prime}$, NonOMURA's classification $^{11)}$, and PrIDHAM and LyONS classification ${ }^{12)}$, shows that the species $S$. lucensis, S. griseoincarnatus, and S. griseorubens resemble our organism with respect to the gray spore mass color, spiral spore chains, and spiny spore surface. Some

Table 2. Carbohydrate utilization by the 4 strains included in the study

\begin{tabular}{l|c|c|c|c}
\hline \multirow{2}{*}{$\begin{array}{l}\text { Utilization } \\
\text { of: }\end{array}$} & \multicolumn{5}{|c}{ Strain } \\
\cline { 2 - 5 } & X-14077 & $\begin{array}{c}\text { S. lu- } \\
\text { censis }\end{array}$ & $\begin{array}{c}\text { S. griseo- } \\
\text { incarnatus }\end{array}$ & $\begin{array}{c}\text { S. griseo- } \\
\text { rubens }\end{array}$ \\
\hline D-Xylose & + & + & + & + \\
L-Arabinose & + & + & + & + \\
D-Glucose & + & + & + & + \\
D-Fructose & + & + & + & + \\
D-Galactose & + & + & + & + \\
L-Rhamnose & - & - & + & + \\
D-Mannitol & \pm & + & + & + \\
i-Inositol & - & - & \pm & + \\
Sucrose & + & + & + & - \\
Salicin & - & - & \pm & - \\
Raffinose & - & - & - & - \\
Cellulose & - & - & - & - \\
\hline
\end{tabular}
similarities are also evident in the pattern of utili-

Table 3. Color of the spore mass and of the reverse substrate mycelium of strain X-14077, S. lucensis, S. griseoincarnatus and S. griseorubens in various media*

\begin{tabular}{|c|c|c|c|c|c|}
\hline Medium & Strain X-14077 & S. lucensis & S. griseoincarnatus & & S. griseorubens \\
\hline \multirow[t]{2}{*}{ ISP-2 } & $\mathrm{U}:$ ashes $(5 f e)$ & $\begin{aligned} \mathrm{U}: & \text { ashes }(5 f e) \text { with } \\
& \text { white specks }\end{aligned}$ & $\begin{aligned} \mathrm{U}: & \text { off-white to silver } \\
& \text { gray }(3 f e)\end{aligned}$ & & $\begin{array}{l}\text { silver gray }(3 f e) \text { to } \\
\text { natural }(3 d c)\end{array}$ \\
\hline & $\begin{aligned} \mathrm{R}: & \text { burgundy } \\
& (71 / 2 \mathrm{pl})\end{aligned}$ & R: oak brown (4pi) & $\begin{aligned} \mathrm{R}: & \text { deep brown }(4 p l) \\
& \text { to oak brown } \\
& (4 p i)\end{aligned}$ & R: & $\begin{array}{l}\text { cinnamon }(3 l e) \text { to } \\
\text { clove brown }(3 \mathrm{ni}) \\
\text { and topaz }(3 \mathrm{ne})\end{array}$ \\
\hline \multirow[t]{2}{*}{ ISP-3 } & $\begin{aligned} \mathrm{U}: & \text { fawn }(4 i g) \\
& \text { cedar }(61 / 2 \text { le }) \\
& \text { in unsporulated } \\
& \text { areas }\end{aligned}$ & $\begin{aligned} \mathrm{U}: & \text { rose beige }(4 \mathrm{ge}) \\
& \text { to lead gray }(5 \mathrm{ih}) \\
& \text { with white edges }\end{aligned}$ & $\begin{aligned} \mathrm{U}: & \text { shell pink }(5 b a) \\
& \text { to pewter }(13 \mathrm{fe}) \\
& \text { Unsporulated } \\
& \text { areas are tan } \\
& \text { yellow. }\end{aligned}$ & & $\begin{array}{l}\text { pussywillow gray } \\
(5 d c) \text { and honey } \\
\text { gold }(2 i c) \text { in } \\
\text { unsporulated areas }\end{array}$ \\
\hline & $\begin{array}{l}\mathrm{R}: \begin{array}{l}\text { rose brown } \\
(61 / 2 n i)\end{array}\end{array}$ & $\mathrm{R}:$ light beige ( $3 e c$ ) & $\begin{array}{l}\mathrm{R}: \text { golden brown } \\
(3 \mathrm{pg}) \text { to topaz } \\
(3 \mathrm{ne})\end{array}$ & $\mathrm{R}$ : & honey gold (2 ic) \\
\hline \multirow[t]{2}{*}{ ISP-4 } & $\mathrm{U}:$ old wine $(7 n g)$ & $\begin{array}{l}\mathrm{U}: \text { ashes }(5 f e) \text { to } \\
\text { white }\end{array}$ & $\mathrm{U}:$ shell pink $(5 b a)$ & & $\begin{array}{l}\text { natural }(3 d c) \text { and } \\
\text { silver gray }(3 f e)\end{array}$ \\
\hline & $\mathrm{R}:$ rose wine $(7 l e)$ & $\begin{array}{ll}\mathrm{R}: & \text { sand }(2 \mathrm{ec}) \text { to } \\
& \text { eggshell }(2 \mathrm{ca})\end{array}$ & $\begin{aligned} \mathrm{R}: & \text { beaver }(4 \mathrm{li}) \text { to } \\
& \text { cinnamon }(3 \mathrm{le})\end{aligned}$ & $\mathrm{R}$ : & covert gray $(2 f e)$ \\
\hline \multirow[t]{2}{*}{ ISP-5 } & $\mathrm{U}$ : rose beige ( $4 \mathrm{ge}$ ) & $\begin{aligned} \mathrm{U}: & \text { rose beige }(4 \mathrm{ge}) \\
& \text { to white }\end{aligned}$ & $\begin{array}{l}\mathrm{U}: \text { white to silver } \\
\text { gray }(3 f e)\end{array}$ & & $\begin{array}{l}\text { off-white on maize } \\
(2 \mathrm{ga}) \text { unsporulated } \\
\text { areas }\end{array}$ \\
\hline & $\mathrm{R}:$ rose beige $(4 \mathrm{ge})$ & $\begin{array}{ll}\mathrm{R}: & \text { natural }(3 d c) \text { to } \\
& \text { eggshell }(2 c a)\end{array}$ & 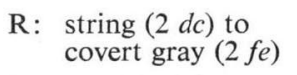 & $\mathrm{R}$ : & maize (2 $g a)$ \\
\hline \multirow[t]{2}{*}{$\begin{array}{l}\text { CZAPEK- } \\
\text { DOX }\end{array}$} & $\begin{aligned} \mathrm{U}: & \text { rosewood } \\
& (5 \mathrm{ge}) ; \text { cocoa } \\
& \text { brown }(5 \mathrm{ni}) \text { in } \\
& \text { unsporulated } \\
& \text { areas }\end{aligned}$ & $\begin{array}{l}\mathrm{U}: \begin{array}{l}\text { pussywillow gray } \\
(5 d c)\end{array}\end{array}$ & $\begin{array}{l}\mathrm{U}: \text { pearl }(3 b a) \text { to } \\
\text { silver gray }(3 f e)\end{array}$ & $\mathrm{U}:$ & shell tint $(3 b a)$ \\
\hline & $\begin{array}{l}\text { R: cocoa brown } \\
(5 \mathrm{ni})\end{array}$ & $\mathrm{R}:$ string $(2 d c)$ & $\begin{array}{l}\mathrm{R}: \text { light } \tan (3 g c) \\
\text { to sand }(2 e c)\end{array}$ & $\mathrm{R}$ : & shell tint $(3 b a)$ \\
\hline
\end{tabular}

* $\mathrm{U}$ : upper surface; $\mathrm{R}$ : reverse mycelium 
Table 4. General morphological and physiological properties of the strains*

\begin{tabular}{|c|c|c|c|c|}
\hline Character & Strain X-14077 & S. lucensis & S. griseoincarnatus & S. griseorubens \\
\hline Color of aerial mycelium & gray & gray & gray & gray \\
\hline Soluble pigment & red & none & none & none \\
\hline Shape of spore chains & RA & $\mathrm{S}$ & $\mathrm{S}$ & $\mathrm{RA}-\mathrm{S}$ \\
\hline Spore surface & spiny & hairy-spiny & spiny & spiny \\
\hline Melanin production & - & + & - & - \\
\hline Starch hydrolysis & + & + & + & + \\
\hline Nitrate reduction & + & + & + & - \\
\hline Gelatin liquefaction & + & ++ & ++ & + \\
\hline Casein hydrolysis & + & + & + & - \\
\hline $\mathrm{NaCl}$ tolerance & $3 \sim 5 \%$ & $4 \%$ & $7 \sim 10 \%$ & $7 \%$ \\
\hline Adenine decomposition & + & + & - & - \\
\hline Xanthine decomposition & - & - & tr. & + \\
\hline Hypoxanthine decomposition & tr. & tr. & + & + \\
\hline Tyrosine decomposition & $\operatorname{tr}$. & - & tr. & + \\
\hline Action on skim milk & $\begin{array}{l}\text { no change; } \\
\text { final } \mathrm{pH}, 6.2 ; \\
\text { pellicle, pink } \\
\text { color at top }\end{array}$ & $\begin{array}{l}\text { peptonization; } \\
\text { final } \mathrm{pH}, 6.6 \text {; } \\
\text { pellicle, } \\
\text { brown color } \\
\text { at top }\end{array}$ & $\begin{array}{l}\text { slight peptoniza- } \\
\text { tion; final } \mathrm{pH} \text {, } \\
6.4 \text {; pellicle, } \\
\text { tan color at top }\end{array}$ & $\begin{array}{l}\text { slight coagula- } \\
\text { tion; peptoniza- } \\
\text { tion; final pH, } \\
6.8 \text {; pellicle, no } \\
\text { pigment** }\end{array}$ \\
\hline
\end{tabular}

* Symbols: RA : retinaculum-apertum (open loops); S: spira (spirals); tr.: traces.

** Results obtained at $36^{\circ} \mathrm{C}$. No growth was observed at $28^{\circ} \mathrm{C}$.

zation of various carbon compounds (Table 2). Colors of the growth in various media for the three strains are presented in Table 3. In general terms, growth characteristics of strain X-14077 and of $S$. lucensis are similar. In both cases the colonies are raised, coarse, with well-defined edges. Instead, S. griseoincarnatus gives flat colonies with diffuse, feathery edges. Other properties of the four strains are presented in Table 4.

The most striking character of strain X-14077 is the production of the deep cherry-red pigment which freely diffuses into the medium. This pigment is produced in most media tested and it becomes evident after 1 or 2 days of incubation. The other 3 cultures do not produce similar pigment.

Other characteristics in which strain X-14077 differs from one or more of the strains of the other 3 species are the following: shape of spore chains, melanin production, nitrate reduction, $\mathrm{NaCl}$ tolerance, the decomposition of purines, and the capacity for growth at the expense of L-rhamnose, $m$-inositol, and sucrose (Tables 3 and 4).

The 4 strains examined in this study show a similar pattern of sensitivity to the antibiotics penicillin, ampicillin, streptomycin, gantrisin, gentamicin, kanamycin, chlortetracycline, chloramphenicol, bacitracin, and streptothricin (Ro 5-4345). Therefore, antibiotic susceptibility has no practical taxonomic value for these microorganisms.

In our opinion, strain X-14077 differs significantly from other species of the genus Streptomyces, and therefore we propose the creation of a new species under the name Streptomyces echinoruber sp. nov., with strain X-14077 (NRRL 8144) as the holotype.

\section{Fermentation and Isolatio : Procedures}

Stock slants of the culture were grown on Bacto Thermoactinomyces fermentation (TAF) medium 
No. $0824-01,24 \mathrm{~g} /$ liter plus $2 \%$ Bacto-Agar, grown at $28^{\circ} \mathrm{C}$ for 5 days, by which time sporulation was abundant. A slant was macerated with distilled water to provide fluid inoculum for 500-ml Erlenmeyer flasks containing $75 \mathrm{ml}$ of the desired medium. The flasks were incubated at $28^{\circ} \mathrm{C}$ on a rotary shaker at $240 \mathrm{rpm}$ for 3 days. This inoculum was used alone, or occasionally combined with about $40 \mathrm{ml}$ of a macerate prepared from the mycelia grown on $20 \mathrm{ml}$ of TAF agar medium cultured 3 days in a $100 \times$ $20 \mathrm{~mm}$ Petri dish. The combined inoculum was used to seed 12 liters of medium in a 14-liter Chemapec bench-scale fermentor. Typically this fermentor medium was of the following composition, in percent by weight in deionized water:

$0.5 \mathrm{~N}-\mathrm{Z}$ Amine-B (enzyme hydrolysate of animal and milk proteins, Humko-Sheffield Chemical Co., Lyndhurst, N. J.); 0.2 yeast extract (Difco Laboratories, Detroit, Michigan); 0.2 soy protein enzyme hydrolysate (Bacto-Soytone, Difco); 1.0 soluble starch (acid-treated starch, No. 178; Difco Labs); 0.5 mannitol; $1 \mathrm{ml}$ of trace elements solution* per liter of medium; 0.01 antifoam (SAG4130, trimethyl polysiloxane aqueous emulsion defoamer, Union Carbide Corp.); $\mathrm{pH} 7.2 \pm 0.2$.

Incubation was usually at $28^{\circ} \mathrm{C}$, with aeration at 4 liters per minute, agitation at $1,200 \mathrm{rpm}$, and atmospheric pressure. After 66 hours, 11 liters of well-developed growth were transferred to 225 liters of the same fermentor medium described above, in a 400 -liter stainless steel fermentor. This fermentor was operated at $28^{\circ} \mathrm{C}$, with aeration at 110 liters/min and atmospheric pressure for 42 hours, then at 70 liters/ min, agitation at $350 \mathrm{rpm}$, and at a back pressure of about $0.35 \mathrm{~kg} / \mathrm{cm}^{2}$. An aliquot was sampled periodically for analysis and microbiological control and harvested at 67 hours. For recovery, $4.55 \mathrm{~kg}$ of diatomaceous earth (Hyflo Super-Cel, Johns-Manville) were added to the tank contents and the broth was centrifugally filtered on a 102-cm perforated-basket centrifuge using a coarse canvas bag on which a precoat layer of filter-aid had been deposited. The filtrate was extracted 3 times with an equal volume of $n$-butanol. Emulsions formed at each extraction were broken by passage through a Sharples AS$26 \mathrm{P}$ centrifuge. Extracts, which contained up to $98 \%$ yield of pigment ( $40 \mathrm{~g}$ of pigment $\mathrm{A}$ ) were pooled and concentrated $20 \sim 40$ fold under reduced pressure below $50^{\circ} \mathrm{C}$ in a Rotator wiped film evaporator. A typical concentrate contained $236 \mathrm{~g}$ of residue which was then further treated ${ }^{21}$ to give pure material.

To follow the amount of pigment produced, the following method of choice was finally adopted: $5 \mathrm{ml}$ of broth supernatant were extracted $1 \sim 3$ times with $5 \mathrm{ml}$ portions of $n$-butanol with mixing for 15 minutes at room temperature. The $n$-butanol layer was separated by centrifuging for 15 minutes at slow speed. Two aliquots of the pooled butanol phases, one of $20 \mu \mathrm{l}$ and one of $40 \mu \mathrm{l}$, were spotted on a silica gel plate with indicator and the plate developed $10 \mathrm{~cm}$ with chloroform - methanol (3:1) for approximately 40 minutes. The spot at Rf 0.13 was then read by densitometry at $525 \mathrm{~nm}$. Alternatively, the plate could be streaked, developed, then scraped and eluted with methanol, and assayed by absorbance at $525 \mathrm{~nm}$. For quantitative estimations, unknown samples were compared with the best available standard. The $\mathrm{E}_{1 \mathrm{~cm}}^{1 \%}$ at $525 \mathrm{~nm}$ of the purest sample during the fermentation development work was 150 , although later preparations were as high as 202 .

\section{Production and Isolation of Pigment}

Strain X-14077 produces one major pigment A (Ro 21-1660) which we have named rubrolone, a minor component B (Ro 21-4958), a third pigment $\mathrm{C}$ which has not been obtained pure, and traces of

* Trace elements solution contained, in $\mathrm{g} /$ liter, $7.5 \mathrm{FeSO}_{4} \cdot 7 \mathrm{H}_{2} \mathrm{O} ; 7.02 \mathrm{Fe}\left(\mathrm{NH}_{4}\right)_{2}\left(\mathrm{SO}_{4}\right)_{2} ; 4.4 \mathrm{ZnSO}_{4} \cdot 7 \mathrm{H}_{2} \mathrm{O}$; $1.54 \mathrm{MnSO}_{4} \cdot \mathrm{H}_{2} \mathrm{O} ; 0.314 \mathrm{CuSO}_{4} \cdot 5 \mathrm{H}_{2} \mathrm{O} ; 0.404 \mathrm{CoCl}_{2} \cdot 6 \mathrm{H}_{2} \mathrm{O} ; 0.572 \mathrm{H}_{3} \mathrm{BO}_{3}$; water to volume. 
several other red compounds. The three pigments $\mathrm{A}, \mathrm{B}$ and $\mathrm{C}$ are readily distinguished by tlc on silica gel F254 plates using chloroform - methanol (3:1) as a developing solvent. The respective Rf values are $\mathrm{A} 0.13, \mathrm{~B} 0.28$, and $\mathrm{C} 0.03$.

A titer of $160 \mathrm{mg}$ pigment A per liter has been achieved in 400-liter fermentors, and titers up to 340 $\mathrm{mg} / \mathrm{liter}$ have been obtained in 14-liter fermentors receiving optimized low aeration ( $0.05 \mathrm{vol}$ air/vol. broth/min.), high agitation, $\mathrm{pH}$ control at $7.2 \sim 8.0$ and nutrient feeding of concentrated TAF medium and mannitol. Pro Flo (partially defatted cooked cottonseed flour, Trader's Oil Mill Co., Fort Worth, Texas) or O. M. Peptone (soluble meat peptone aqueous concentrate, Oscar Mayer, Madison, Wisconsin) were effective nitrogen substitutes for soytone in total pigment production. Two dextrins, Staley No. 11 and Stadex 60K (A. E. Staley) were found to be as effective as soluble starch, and less expensive. Sorbose, sorbitol, glycerol and mannose did not support pigment production, while lactose was almost as effective as mannitol. Glucose substitution for mannitol led to the production of a pigment which moved more rapidly on tlc plates than pigment A. A high pigment production in shake flasks was also possible in a medium containing $1.5 \%$ debittered dried yeast, $1 \%$ cornstarch, $0.1 \% \mathrm{CaCO}_{3}, 0.1 \%$ $\mathrm{K}_{2} \mathrm{HPO}_{4}$ and $3 \%$ corn oil, $\mathrm{pH} 7.0$, in addition to the TAF medium.

For recovery, $75 \sim 80 \%$ of the pigment was removed after a single extraction of broth filtrate with an equal volume of $n$-butanol. The remainder of the pigment could be recovered with a second or third extraction. Such butanol extracts were concentrated under reduced pressure, and further purified by column chromatography, as described separately. ${ }^{2)}$ Recovery was poor when the broth was extracted with chloroform, carbon tetrachloride, ethyl acetate, methyl isobutyl ketone or hexane.

\section{Biological Properties of Pigment A}

When tested at a concentration of $1 \mathrm{mg} / \mathrm{ml}$ against 19 microorganisms by agar diffusion cup-plate assay, pigment A gave no inhibitory activity. Included in the test organisms were: Pseudomonas aeruginosa, Proteus vulgaris, Escherichia coli, Klebsiella pneumoniae, Serratia marcescens, Serratia sp. 101, Acinetobacter calcoaceticus, Staphylococcus aureus, Sarcina lutea, Bacillus megaterium, Bacillus sp. E, Bacillus subtilis, Bacillus sp. TA, Mycobacterium phlei, Streptomyces cellulosae, Paecilomyces varioti, Penicillium digitatum, Candida albicans, and Saccharomyces cerevisiae.

The acute mouse toxicity of rubrolone (pigment A, Ro 21-1660/002, lot $\$ 3217-122 \mathrm{~A}$, with an estimated $80 \%$ purity) was found to be $\mathrm{LD}_{50} \pm$ S. E., $\mathrm{mg} / \mathrm{kg},>4,000$ p. o. and $930 \pm 205$ i. p. A slightly less pure preparation (Ro 21-1660/1, lot $\$ 3217-38 \mathrm{AA}$ ) gave in mice an $\mathrm{LD}_{50}, \mathrm{mg} / \mathrm{kg}$ of $>1,000$ p.o. and i.p. At a dose of $250 \mathrm{mg} / \mathrm{kg}$ i.p., rubrolone was inactive in the Sarcoma 180 and EHRLICH solid carcinoma experimental mouse models, and also inactive at 250 p.o. in the leukemia L1210 ascites model.

\section{Tinctorial Power and Stability}

Neutral solutions of one unit of FD\&C Red No. 2 (amaranth) appear to be equal to two units of our red pigment. However, at $\mathrm{pH} 3$ and 5 the color intensity of pigment $\mathrm{A}$ increases and it becomes equal to that of Red No. 2. The color of unautoclaved and autoclaved solutions at pH 3, 5 and 7 appears stable. At room temperature and $\mathrm{pH} 6.4$ or in $2 \%$ citric acid solution, no visible change in color was observed after 1 month. Although pigment $\mathrm{A}$ is as stable as Red No. 2 to normal light conditions, it is less stable to strong reducing agents such as ascorbic acid, and it is immediately decolorized in sodium bisulfite 
solution. Additional results on tinctorial power will be presented in a forthcoming publication by A. EMODI and H. NeWMARK ${ }^{3 !}$.

\section{Acknowledgements}

We thank Dr. W. Pool and Ms. D. Hane for the toxicity data, Dr. W. DeLorenzo and Dr. R. Cleeland for the chemotherapeutic data, Dr. R. JOSSE for the results on tinctorial power and stability, and Mrs. M. ARTEAGA and Dr. A. MLODOZENIEC for their collaboration on the scanning electron micrographs.

\section{References}

1) Berger, J.; K.E. Reichelt \& W. Schuep: Certain pyrano-furo-azuleno-pyridines. U.S. Patent 4,057,553, Nov. 8, 1977

2) Schüep, W.; J. F. Blount, T. H. Williams \& A. Stempel: Production of a novel red pigment, rubrolone, by Streptomyces echinoruber sp. nov. II. Chemistry and structure elucidation. J. Antibiotics 31: 1226 1232,1978

3) Emodi, A. \& H. Newmark: to be published

4) Shirling, E. B. \& D. Gotrlieb: Methods for characterization of Streptomyces species. Internat. J. Syst. Bacteriol. 16: 313 340, 1966

5) Gordon, R. E. \& M. M. Smith: Rapidly growing acid-fast bacteria. J. Bacteriol. 66: 41 48, 1953

6) Skerman, V. B. D.: A guide to the identification of the genera of bacteria. p. 253 The Williams and Wilkins Co., Baltimore, 1967

7) Gordon, R. E.: The taxonomy of soil bacteria. In T. R. G. Gray \& D. PArkinson (ed.), Ecology of Soil Bacteria. pp. 293 321, Liverpool University Press, Liverpool, 1974

8) Becker, B.; M. P. Lechevalier, R. E. Gordon \& H. A. Lechevalier: Rapid differentiation between Nocardia and Streptomyces by paper chromatography of whole-cell hydrolysates. Appl. Microbiol. 12: $421 \sim 423,1964$

9) Williams, S. T.; F. L. Davies \& T. Cross: Identification methods for microbiologists. Part B, Soc. for Appl. Bacteriol., Tech. Series \#2, 1966

10) Buchanan, R. E. \& N. E. Gibbons (ed): Bergey's Manual of Determinative Bacteriology, 8th edition. pp. 748 829, The Williams and Wilkins Co., Baltimore, 1974

11) Nonomura, H.: Key for classification and identification of 458 species of streptomycetes included in ISP. J. Ferment. Technol. 52: 78 92, 1974

12) Pridham, T. G. \& A. J. Lyons, Jr.: Progress in clarification of the taxonomic and nomenclatural status of some problem actinomycetes. Dev. Ind. Microbiol. 10: 183 221, 1969

13) Waksman, S. A.: The Actinomycetes. Vol. 2, p. 330, The Williams and Wilkins Co., Baltimore, 1961

14) JoNES, K. L.: Fresh isolates of actinomycetes in which the presence of sporogenous aerial mycelium is a fluctuating characteristic. J. Bacteriol. 57: 141 145, 1949

15) Hickey, R. J. \& H. D. Tresner: A cobalt-containing medium for sporulation of streptomyces species. J. Bacteriol. 64: 891 892, 1952 